\section{'It's the progression, doctor': what patients with motor neurone disease really are interested in}

\author{
Julian Grosskreutz
}

To see a patient and recognise amyotrophic lateral sclerosis as the underlying cause of progressive, painless paralysis without sensory symptoms has been deemed easy, and indeed it is for physicians seeing patients with motor neuron disease on a regular basis. Answering patients' questions of 'How bad is it? What will happen to me? How long do I have?' is however no mean feat; these questions invariably challenge the treating physician to perform a thorough assessment of the extent and the aggressiveness of the disease. While the Amyotrophic lateral sclerosisfunctional rating scale (ALSFRS-R) provides a quantitative measure of functional deficits, it does not follow a linear time course and has limited predictive capability compared to vital capacity. ${ }^{1}$

The individual causal mechanisms underlying ALS are largely unknown. Despite rapid advances associating more than 60 genes with ALS, few of these predict progression. ${ }^{2}$ Only recently, phosphorylyated neurofilament heavy chain and neurofilament light chain in corticospinal fluid and serum have been associated with disease load and progression, ${ }^{3}$ while postmortem studies have identified neuropathological stages of ALS as a progressive spread of pathology from the motor cortex to all monosynaptically connected areas of the brain. ${ }^{4}$ Yet none of these markers allow individual prediction of the disease course or the extent of extramotor involvement.

Correspondence to Dr Julian Grosskreutz, Hans Berger Department of Neurology, Jena University Hospital, Am Klinikum 1, Jena 07747, Germany; julian. grosskreutz@med.uni-jena.de
High-resolution MRI is now being increasingly used to identify pathology variants in different forms of ALS in vivo. In their JNNP paper, Senda and colleagues $^{5}$ have performed stateof-the-art multimodal MRI in 67 patients with ALS consecutively seen in their clinic. They identified significant ALS-related changes in the brain that correlated with a more aggressive disease course as inferred by ALSFRS-R progression of 6 months after the initial scan. While this group analysis does not allow prognostication of disease progression on an individual basis, it provides a major step forward to answer that all pervading question of 'What will happen to me?' because most areas that were associated with a more aggressive disease course were extramotor brain areas. In contrast to ALSFRS-R and vital capacity, MRI allows the detection of the involvement of brain areas that have a significant impact on the patient's ability to fully comprehend the long-term implications of the ALS diagnosis. These may entail decisions on care modalities, of mobility and ventilatory support, with the latter allowing the patient to survive for a prolonged time period, in some cases beyond the ability to make an informed decision on continuation of ventilation.

In the future, MRI further developed to aid an individual assessment of the extent of extramotor brain involvement should assist physicians to recognise a reduction in the patient's ability to make long-term decisions, something most patients would like to know about erly in the course of ALS.
Correction notice Since this paper was first published online updates have been made to references 4 and 5.

Competing interests None declared.

Provenance and peer review Commissioned; internally peer reviewed.

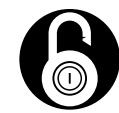

\section{OPEN ACCESS}

Open Access This is an Open Access article distributed in accordance with the Creative Commons Attribution Non Commercial (CC BY-NC 4.0) license, which permits others to distribute, remix, adapt, build upon this work non-commercially, and license their derivative works on different terms, provided the original work is properly cited and the use is non-commercial. See: http:// creativecommons.org/licenses/by-nc/4.0/

(C) Article author(s) (or their employer(s) unless otherwise stated in the text of the article) 2017. All rights reserved. No commercial use is permitted unless otherwise expressly granted.

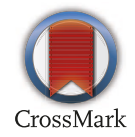

To cite Grosskreutz J. J Neurol Neurosurg Psychiatry 2017;88:897.

Received 13 May 2017

Revised 9 February 2017

Accepted 17 May 2017

Published Online First 28 July 2017

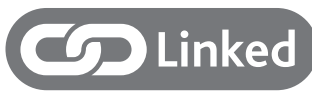

- http://dx.doi.org/10.1136/jnnp-2016-314337

J Neurol Neurosurg Psychiatry 2017;88:897.

doi:10.1136/jnnp-2017-316001

\section{REFERENCES}

1 Kaufmann P, Levy G, Thompson JL, et al. The ALSFRSr predicts survival time in an ALS clinic population. Neurology 2005;64:38-43.

2 Al-Chalabi A, van den Berg LH, Veldink J. Gene discovery in amyotrophic lateral sclerosis: implications for clinical management. Nat Rev Neurol 2017;13:96-104.

3 Poesen K, De Schaepdryver M, Stubendorff B, et al. Neurofilament markers for ALS correlate with extent of upper and lower motor neuron disease. Neurology 2017;88:2302-9.

4 Braak H, Brettschneider J, Ludolph AC, et al. Amyotrophic lateral sclerosis - a model of corticofugal axonal spread. Nat Rev Neurol 2013;9:708-14.

5 Senda J, Atsuta N, Watanabe H, et al. Structural MRI correlates of amyotrophic lateral sclerosis progression. J Neurol Neurosurg Psychiatry 2017;66:901-7. 